\title{
Bumi di Bawah Tekanan: COVID-19 dan Polusi Plastik
}

\author{
Maya Nabila Roxanne ${ }^{1 *}$
}

${ }^{1}$ Universitas Indonesia, Indonesia

\author{
A R T I C L E I N F O \\ Article history: \\ Received 08 Januari 2021 \\ Accepted 01 Mei 2021 \\ Available online 30 Juni \\ 2021 \\ Kata Kunci: \\ COVID-19; Perubahan \\ Perilaku; Pembelanjaan \\ Daring; Pengelolaan Sampah \\ Plastik; Antropologi \\ Keywords: \\ COVID-19; Behaviour \\ Changes; Online Shopping; \\ Plastic Waste Management; \\ Anthropology
}

\begin{abstract}
A B S T R A K
Sampah plastik merupakan tantangan yang memprihatinkan dan sebagian besar disebabkan oleh pertumbuhan, kemajuan, dan modernisasi. Kehadiran COVID-19 yang bermula di kota Wuhan di Tiongkok kemudian menyebar dengan cepat ke berbagai belahan negara di dunia telah merubah segala bentuk kegiatan dan penutupan akses dalam berbagai sektor oleh pemerintahan di seluruh dunia hingga sebagian besar pekerjaan terpaksa dilakukan dari rumah. Pemerintah Indonesia menerapkan Pembatasan Sosial Berskala Besar (PSBB) yang mengakibatkan perubahan tatanan kehidupan mulai dari adaptasi kebiasaan baru untuk memakai masker setiap hari hingga ketergantungan rumah tangga pada layanan pengiriman baik makanan maupun belanja kebutuhan harian yang berdampak pada meningkatnya volume sampah plastik. Dengan studi literatur dan data sekunder dari portal berita, artikel ini bertujuan untuk mengkaji perubahan perilaku konsumsi dalam rumah tangga yang terjadi secara daring selama pandemi yang mengakibatkan
\end{abstract} peningkatan polusi plastik pada lingkungan dengan menggunakan konsep Mary Douglas tentang "matter out of place" dan konsep material culture. Hasil penelitian menunjukkan bahwa ketergantungan masyarakat akan plastik secara global bertambah saat COVID-19. Konsumsi pembelanjaan daring berbentuk paket meningkat menjadi $62 \%$ dan layanan pesan antar makanan sebesar $47 \%$. Hal ini perlu diimbangi dengan pengelolaan sampah yang lebih terstruktur sehingga tidak memicu krisis lingkungan di masa depan, pasalnya 96\% pembelanjaan daring tersebut mengandung materi plastik yang berimplikasi pada peningkatan persentasi volume sampah plastik dan menimbulkan kekhawatiran jangka panjang yang serius dari perspektif lingkungan.

\section{A B S T R A C T}

Plastic waste is alarming and mainly due to growth, progress, and modernization. The presence of COVID19 , which began in the city of Wuhan in China, then spread rapidly to various parts of the world and has changed all forms of activities and the closure of access in various sectors by governments around the world so that most of the work has to be done from home. The Government of Indonesia implements a Large-Scale Social Restriction (PSBB), which results in changes in the structure of life ranging from the adaptation of new habits to wearing masks every day to the dependence of households on delivery services for both food and daily necessities, which have an impact on increasing the volume of plastic waste. By studying literature and secondary data through news portals, this article examines the changes in household consumption behavior that occurred online during the pandemic that resulted in increased plastic pollution in the environment using the Mary Douglas approach, "matter out of place," the concept of material culture. The results show that people's dependence on plastic globally has increased during COVID-19. Consumption of online purchases in packages increased to $62 \%$ and food delivery services by $47 \%$. This needs to be balanced with more structured waste management so that it does not trigger an environmental crisis in the future because $96 \%$ of online purchases contain plastic material which has implications for increasing the percentage of plastic waste volume and raises serious long-term concerns from an environmental perspective. 


\section{Pendahuluan}

Pandemi COVID-19 merubah segala bentuk kegiatan dan penutupan akses dalam berbagai sektor oleh pemerintah di seluruh dunia, mulai dari sekolah dan kuliah hingga kerja semua terpaksa dilakukan dari rumah. Dina Rahmawati (2020) memaparkan dalam portal berita SehatQ bahwa COVID-19 bermula di kota Wuhan di Tiongkok yang kemudian menyebar dengan cepat ke berbagai belahan negara di dunia. Wabah virus COVID-19 ditetapkan sebagai pandemi oleh World Health Organization (WHO) pada Maret 2020 silam.

Berdasarkan data dari WHO (2020), pada 28 November 2020 telah terkonfirmasi $61,036,793$ kasus positif COVID-19 dari seluruh dunia dengan total 1,433,316 orang meninggal dunia karenanya. Hingga saat ini Amerika Serikat masih menduduki peringkat pertama untuk jumlah kasus positif dan korban jiwa (WHO, 2020). Sementara situasi COVID-19 di Indonesia pada hari yang sama (lihat gambar 1) telah mencapai 527,999 kasus positif yang tersebar di 34 provinsi dengan total kesembuhan sebanyak $83,7 \%$ atau sejumlah 441,983 orang dan 16,646 orang meninggal dunia (Gugus Tugas Percepatan Penanganan COVID-19, 2020).

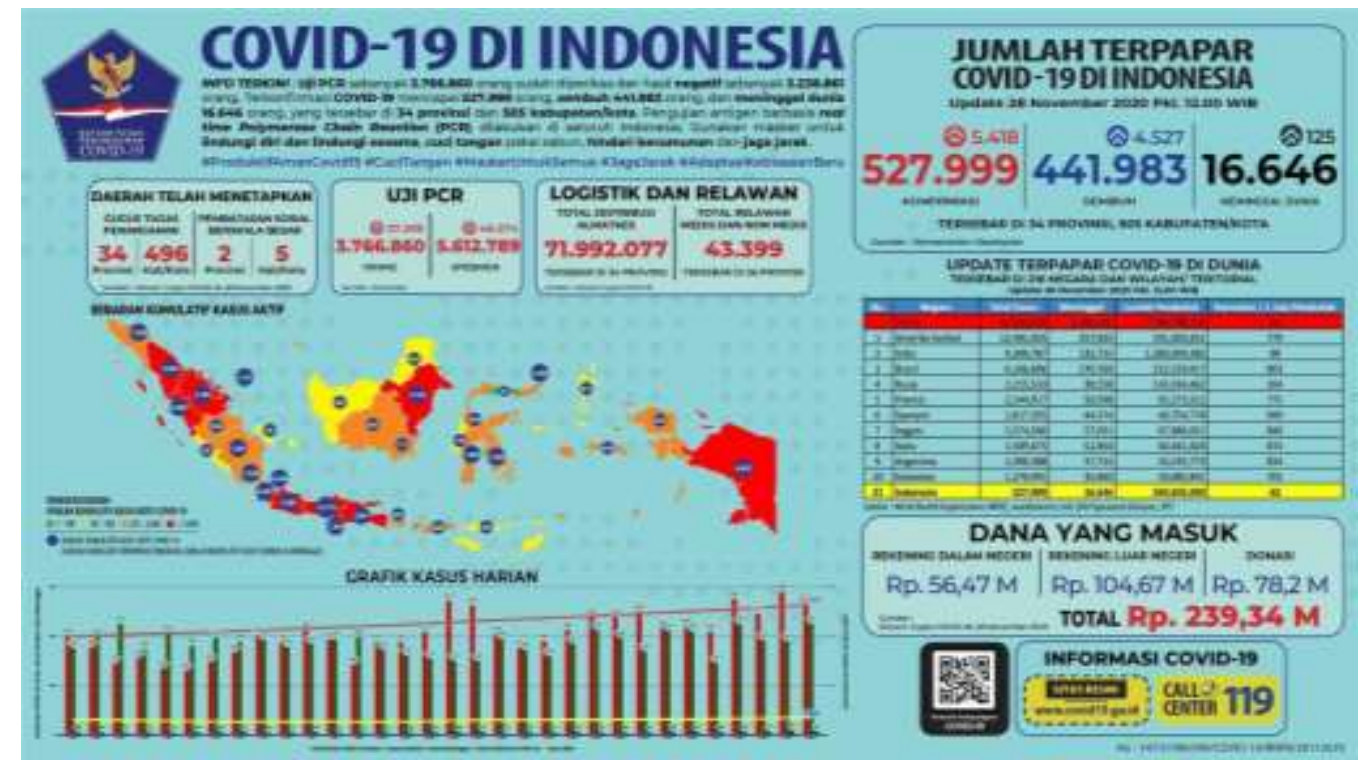

Gambar 1. Peta Sebaran COVID-19 di Indonesia pada 28 November 2020 Sumber: BNPB Indonesia, 2020

Pandemi COVID-19 telah memaksa sejumlah negara melakukan karantina secara keseluruhan yang kerap disebut dengan lockdown, sementara di Indonesia, berdasarkan pada Keputusan Presiden Nomor 11 Tahun 2020 tentang Penetapan Kedaruratan Kesehatan Masyarakat Corona Virus Disease 2019 (COVID-19) mewajibkan untuk dilakukan upaya penanggulangan berupa penyelenggaraan kekarantinaan kesehatan sebagaimana telah diatur dalam Undang-Undang Nomor 6 Tahun 2018 tentang Kekarantinaan Kesehatan. Salah satu tindakan kekarantinaan kesehatan berupa Pembatasan Sosial Berskala Besar (PSBB) sebagaimana diatur dalam Peraturan Menteri Kesehatan Republik Indonesia Nomor 9 Tahun 2020 yang ditetapkan pada 3 April 2020 silam, pada BAB III Pasal 13 Nomor 1 menyatakan bahwa pelaksanaan PSBB meliputi (a) peliburan sekolah dan tempat kerja; (b) pembatasan kegiatan keagamaan; (c) pembatasan kegiatan di tempat atau fasilitas umum; (d) pembatasan kegiatan sosial dan budaya; (e) pembatasan moda transportasi; dan (f) pembatasan kegiatan lainnya khusus terkait aspek pertahanan dan keamanan. Segala upaya ini dilakukan untuk mencegah penularan dan sekaligus untuk melandaikan kurva laju penyebaran COVID-19 di dalam negeri.

Adanya resiko akan tertular virus COVID-19 telah meningkatkan kesadaran masyarakat akan kesehatan yang kemudian mengubah perilaku menjadi lebih higienis. Hal ini turut menggeser pola perilaku konsumen seperti penggunaan Alat Pelindung Diri (APD), meningkatnya pembelian barang dan makanan melalui daring menggunakan kemasan plastik, dan penggunaan 
peralatan sekali pakai lainnya (Vanapalli, 2020). McRobert et al. (2020), menyatakan berdasarkan dari laporan pengelolaan sampah di Amerika Utara pada Juli 2020 terjadi peningkatan volume sampah plastik sebesar $50 \%$ terjadi pada rumah tangga. Faktor pendorong: (1) ketergantungan pada APD, (2) peningkatan tajam dalam industri pedagang elektronik; konsumen merasa lebih aman tinggal di rumah dan barang/makanan dikirim kepada mereka, (3) peningkatan layanan penjemputan konsumen di pinggir jalan oleh penyedia layanan (McRobert et al, 2020). Dilansir dalam BBC News Indonesia (2020), selama pandemi COVID-19 penggunaan pembungkus dan kantong plastik sekali pakai juga mengalami peningkatan sehingga memperburuk masalah sampah plastik yang sudah ada di Indonesia sebelum pandemi terjadi. Peraturan Gubernur DKI Jakarta Nomor 142 Tahun 2019 hanya melakukan pelarangan penggunaan kantong plastik sekali pakai pada pusat perbelanjaan luring dan tidak mencakup kantong plastik yang digunakan untuk pembelanjaan secara daring. Andono Warih, Kepala Dinas Lingkungan Hidup Provinsi DKI Jakarta mengakui bahwa mereka belum bisa mengendalikan konsumsi plastik yang terjadi pada pembelanjaan yang terjadi secara daring (Yuniar, 2020). Koordinator Nasional Gerakan Indonesia Diet Kantong Plastik, Rahyang, juga berpendapat bahwa layanan pesan antar makanan daring seperti GO-FOOD dan GRABFOOD tersebut menjadi sektor yang susah dikendalikan (Yuniar, 2020). Sistem pengelolaan sampah yang tidak memadai dan efisien untuk menangani ketergantungan yang meningkat pada plastik dapat memperburuk kesalahan pengelolaan dan kebocoran ke lingkungan, sehingga dapat memicu krisis lingkungan baru di masa mendatang (Vanapalli et al., 2020).

Riset terbaru dari Lembaga Demografi Fakultas Ekonomi dan Bisnis Universitas Indonesia (LD FEB UI) menunjukkan bahwa terjadi perubahan pola penggunaan layanan daring oleh konsumen selama pandemi COVID-19 berlangsung, yaitu konsumen semakin bergantung pada layanan berbasis aplikasi daring seperti GO-JEK (Hamdana R, 2020). Dipaparkan oleh LD FEB UI, layanan yang paling sering digunakan secara berurutan adalah GO-FOOD (65\%), GO-PAY (68\%), PAYLATER (57\%) dan GO-SEND (36\%). Taufik Hidayat (2020: VII-1) dalam penelitiannya di Kota Medan menyatakan bahwa penerapan work from home, social distancing, dan pembatasan jumlah pengunjung restoran selama pandemi COVID-19 berdampak signifikan secara parsial dan simultan terhadap peningkatan pembelian makanan secara daring melalui aplikasi GO-FOOD. Sejalan dengan itu, hasil riset dari LD FEB UI juga menyatakan bahwa sebanyak 86\% konsumen mengaku aplikasi daring tersebut membantu mereka untuk beradaptasi dengan kebiasaan baru dan tetap produktif selama pandemi COVID-19 (Hamdana R, 2020). Peningkatan jumlah transaksi pada layanan pesan antar makanan dengan persentase yang sama juga terjadi pada perusahaan layanan jasa serupa, GRAB (Yuniar, 2020).

Bahaya polusi plastik telah memobilisasi pemerintah global, perusahaan bisnis, dan komunitas lokal untuk memerangi penyebarannya di lingkungan (Schnurr et al., 2018; dalam Vanapalli et al., 2020; hlm.2). Neumeyer, Ashton, dan Dentchev (2020) berpendapat bahwa kewirausahaan merupakan agen perubahan yang penting dalam membantu mengatasi tantangan terhadap sumber daya dan pengelolaan limbah yang terjadi akibat COVID-19. Banyak wirausahawan mengesampingkan pengelolaan limbah dan masalah sumber daya karena berjuang untuk bertahan hidup, padahal krisis yang terjadi saat ini seharusnya dapat dimanfaatkan sebagai faktor pendorong untuk keberlanjutan lingkungan di masa depan, mereka lantas mengidentifikasikan tiga kebutuhan terkait peran kewirausahaan tersebut (Neumeyer et al, 2020). Penyedia layanan aplikasi daring, GO-FOOD dan GRABFOOD, mengakui sudah melakukan beberapa cara untuk mengurangi konsumsi plastik sekali pakai, namun hasil survei yang dilakukan oleh Pusat Penelitian Oseanografi dan Pusat Penelitian Kependudukan Lembaga Ilmu Pengetahuan Indonesia menyatakan bahwa 96\% paket yang dibeli melalui daring mengandung materi plastik seperti selotip, pembungkus plastik dan bubble wrap (Yuniar, 2020). Survei tersebut menunjukkan bahwa selama pandemi COVID-19, jumlah responden yang melakukan pembelanjaan daring berbentuk paket meningkat menjadi 62\% sementara layanan pesan antar makanan siap saji meningkat sebesar 47\% (Yuniar, 2020).

Terlepas dari segala sisi negatifnya, pandemi COVID-19 ternyata juga memiliki sisi positif bagi lingkungan yaitu terjadi penurunan drastis polusi dan emisi gas rumah kaca di banyak negara 
(McRobert et al, 2020), bahkan penutupan akses yang dilakukan di India untuk pertama kalinya dalam 30 tahun sukses membuat masyarakat India bisa melihat puncak Himalaya dari jarak 200 $\mathrm{km}$ (Wirakusuma, 2020). Sementara di Indonesia polusi udara juga turut membaik di banyak kota besar, CNBC Indonesia (2020) bahkan menuliskan bahwa polusi di DKI Jakarta turun ke level terendah dalam 3 tahun terakhir selama penetapan PSBB, Kepala BMKG mengatakan penurunan konsentrasi debu polutan ini dipengaruhi juga oleh hujan yang turun karena proses rain washing (pencucian atmosfer). Dengan studi literatur dan data sekunder dari portal berita, artikel ini bertujuan untuk mengkaji perubahan perilaku konsumsi dalam rumah tangga yang terjadi secara daring selama pandemi yang mengakibatkan peningkatan polusi plastik pada lingkungan dengan menggunakan konsep Mary Douglas tentang "matter out of place" dan konsep material culture.

\section{Metode}

Metode ilmiah dari ilmu pengetahuan adalah segala jalan atau cara dalam rangka ilmu tersebut untuk sampai kepada kesatuan pengetahuan, dengan melakukan (1) pengumpulan fakta, (2) penentuan ciri-ciri umum dan sistem, dan (3) verifikasi (Koentjaraningrat, 2002). Dengan melihat keadaan yang serba terbatas saat ini sebagai akibat dari pandemi COVID-19, maka metode yang digunakan pada artikel ini adalah studi literatur penelitian terdahulu dan didukung dengan data sekunder dari portal berita daring beserta referensi lainnya yang dikutip dalam artikel ini yang digunakan sebagai basis dalam memahami topik yang dikaji pada penelitian ini juga untuk melihat fakta yang terpampang pada kenyataan yang ada secara lebih luas.

\section{Hasil dan Pembahasan}

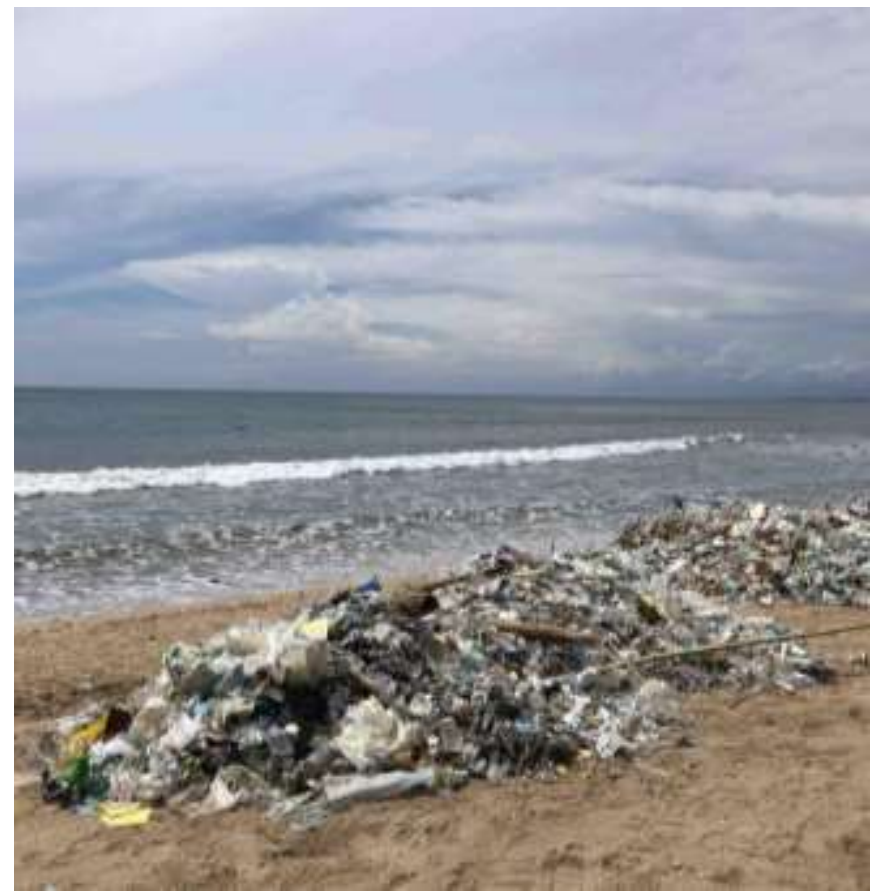

Gambar 2. Tumpukan Sampah Plastik dari Laut di Pantai Kuta, Bali Sumber: dokumentasi pribadi (6 Januari 2021)

Sampah plastik merupakan tantangan yang memprihatinkan (lihat gambar 2) dan sebagian besar disebabkan oleh pertumbuhan, kemajuan, dan modernisasi (Schlehe \& Yulianto, 2020; hlm. 41). Berdasarkan data yang dirilis oleh Jambeck (2015) menyatakan Indonesia sebagai pencemar laut terbesar kedua di dunia setelah Cina. Pada tahun 2010 Indonesia diperkirakan menghasilkan 3.2 juta ton sampah plastik yang salah dikelola dan 1.29 juta ton diantaranya berakhir di laut (Jambeck, 2015; dikutip dalam Schlehe \& Yulianto, 2020; hlm. 41). Secara keseluruhan 
diperkirakan hampir 15\% sampah plastik dari total global yang bermuara di lautan berasal dari Indonesia dengan empat sungai di Jawa yang diidentifikasi sebagai penyumbang utama yakni Sungai Brantas, Solo, Serayu, dan Progo. Realitas ini mencerminkan tingkat kepadatan penduduk, serta kesalahan pengelolaan sampah di wilayah tersebut (Lebreton et al, 2017; hlm. 4). Tidak hanya lautan dan kehidupan laut kita yang sangat terpengaruh oleh polusi plastik; tetapi penduduk lokal di Indonesia yang hidup berdampingan dengan polusi plastik. Para peneliti dalam bidang studi sains dan teknologi tentunya sudah meneliti masalah kesehatan dan lingkungan yang terkait dengan merebaknya sampah plastik. Terutama bagaimana sampah plastik saat ini telah berubah bentuk menjadi partikel nano yang disebut dengan microplastic dan memasuki rantai makanan global, bersama dengan bahan kimia pengganggu endokrin (EDC) yang digunakan sebagai aditif untuk membuat plastik lebih lentur (Liboiron 2016; Meeker et al. 2009; dikutip dalam Pathak \& Nichter, 2019; hlm. 308).

Drackner (2005; hlm. 175) menyampaikan pula bahwa perspektif antropologis tentang sampah mengeksplorasi fakta bahwa apa yang disebut dengan limbah adalah gagasan yang sangat subyektif. Sampai dengan saat ini pun belum terlihat jelas ada fokus khusus yang dilakukan dari peminatan antropologi terhadap sampah plastik yang padahal merupakan salah satu masalah kesehatan lingkungan dan global nomor satu saat ini. Unsur-unsur yang membuat plastik sangat fleksibel dan dicari-sifat kedap dan daya tahannya-juga berarti bahwa mereka menumpuk daripada membusuk (Pathak \& Nichter, 2019; hlm. 308). Mary Douglas berpendapat bahwa semua budaya modern memiliki konsep tentang apa yang murni dan tidak murni, bersih dan tabu. Purity and Danger adalah argumen antropologis tentang bagaimana konsep-konsep ini diciptakan, menjelaskan bahwa apa yang dikategorikan dengan sampah itu bergantung pada 'the matter out of place'. Douglas dalam buku ini menyampaikan bahwa ide tentang sampah terdiri dari dua hal, menjaga kebersihan dan menghormati kebiasaan atau adat dan ketentuan yang berlaku. Aturan terkait kebersihan dapat berubah seiring dengan perubahan pengetahuan kita namun demikian hal ini dapat dikesampingkan demi kekerabatan (Douglas, 2001; hlm. 7). Gagasan kita tentang kebersihan telah menjadi sangat terspesialisasi dan dalam beberapa budaya, kesucian adalah gagasan yang sangat umum yang tidak lebih dari sekadar larangan (Douglas, 2001; hlm. 8). Mungkin semua sistem sosial dibangun di atas kontradiksi, dalam arti tertentu berperang dengan diri mereka sendiri. Tetapi dalam beberapa kasus, berbagai tujuan yang didorong untuk dikejar oleh individu-individu terkait lebih harmonis daripada tujuan lainnya (Douglas, 2001; hlm. 141).

Joshua Reno (2015) memberi gagasan luas terkait apa yang dianggap dengan sampah itu sendiri namun lebih menitik beratkan perihal pengelolaan sampah. Dalam artikelnya Waste and Waste Management, Reno menyatakan bahwa apa yang dikonsepkan sebagai "sampah" itu bergantung pada konteks yang sedang dibahas dan oleh siapa. Lebih lanjut, pengelolaan sampah oleh Reno (2015; hlm. 559) dikatakan adalah bagian dari apa yang membuat kita menjadi diri etis yang kita inginkan (Hawkins, 2006). Pengelolaan sampah tergantung pula dari objeknya, apabila 'sampah' tersebut dianggap masih dapat memiliki manfaat bagi orang lain maka akan dipindah tangankan, seperti halnya barang-barang yang dijual melalui garage sale maupun yang diberikan begitu saja kepada orang lain secara cuma-cuma melalui badan amal misalnya. Ini juga dapat terjadi dengan cara yang kurang permanen, seperti ketika barang-barang disimpan sementara di dalam gudang dengan kemungkinan reklamasi atau berujung pada pembuangan di masa depan. Pembuangan benda-benda ini dapat mendistorsi persepsi tentang kenyataan. Meskipun mungkin barang-barang tak terpakai tersebut hanya diletakkan dalam gudang namun sudah tidak kasat mata, akhirnya dianggap sudah tidak ada sampah berserakan lagi. Bagaimanapun, orang akan tetap hidup dalam batasan dan kebebasan mereka masing-masing, baik secara bersamaan menantang maupun mempertahankan sistem pengolahan sampah yang sudah diciptakan (Reno, 2015).

Penelitian yang berfokus pada kasus rumah susun di Toronto, Kanada, menyatakan pandemi COVID-19 memiliki banyak konsekuensi lingkungan, termasuk dampak pada sistem pengelolaan sampah kota. Perubahan pola dan perilaku konsumsi dan pembuangan limbah selama periode lockdown menimbulkan tantangan baru bagi kegiatan pengelolaan sampah dan 
pengalihan sampah (Ikiz et al, 2020). Penelitian LIPI menyatakan terdapat perbedaan yang cukup tinggi antara kesadaran dan aksi nyata yang dilakukan masyarakat dalam kehidupan sehari-hari terkait pengelolaan sampah plastik di rumah tangga, yang hampir $100 \%$ responden menjawab penting untuk memilah plastik di rumah tangga namun hanya $50 \%$ diantaranya yang benar-benar melakukan praktik pemilahan tersebut sehari-hari (Yuniar, 2020). Menurut survei yang dilakukan oleh Indonesia National Plastic Action Partnership pada tahun 2017, hanya 10\% dari 6,8 juta ton sampah plastik yang didaur ulang di 1.300 pusat daur ulang di Indonesia setiap tahunnya (Yuniar, 2020). Survei yang dilakukan oleh LIPI juga menyatakan bahwa $16 \%$ sampah plastik yang berada di Teluk Jakarta saat ini merupakan sampah APD seperti masker dan sarung tangan. Hasil ini sesuai dengan survei yang dilakukan oleh Pusat Penelitian Oseanografi dan Pusat Penelitian Kependudukan Lembaga Ilmu Pengetahuan Indonesia yang menunjukkan pembelanjaan APD seperti masker, face shield, dan sarung tangan melonjak pesat dari $4 \%$ sebelum pandemi menjadi 36\% (Yuniar, 2020). Meski demikian LIPI memaparkan bahwa timbunan sampah secara keseluruhan di perkotaan selama pandemi mengalami penurunan yang cukup signifikan yaitu sebesar $10 \%$, namun demikian kategori sampah plastik sekali pakai yang dianggap sebagai sampah infectious akibat terpapar udara mengalami kenaikan (Yuniar, 2020).

Dalam artikelnya, McRobert, Jordan dan Ostrum (2020) berusaha menguraikan dampak sosial-ekonomi dan lingkungan yang disebabkan oleh pandemi COVID-19 yang telah menyebabkan ketakutan yang berlebih di antara orang Kanada, terutama pada tahap awal, sehingga banyak masyarakat yang melakukan panic buying dan penimbunan beragam barang di rumah mereka seperti kertas toilet, pembersih tangan, perlengkapan pembersih dan kebutuhan lainnya. Seketika konsumsi plastik mengalami peningkatan tajam secara global, tidak hanya karena ketersediaan yang mudah dan murah, namun karena potensi plastik sebagai APD dan kemasan makanan. Pergeseran dari penggunaan kemasan yang dapat digunakan kembali menjadi ketergantungan pada produk plastik sekali pakai di banyak sektor, sementara kegiatan daur ulang menurun dan perilaku membuang sampah sembarangan di darat dan laut meningkat serta didukung pula oleh pengelolaan sampah yang buruk menimbulkan ironi bahwa perilaku buruk ini juga berisiko bagi kesehatan masyarakat Kanada itu sendiri. Sampah yang dibuang secara tidak benar dapat menjadi vektor virus COVID-19 yang secara teoritis dapat bertahan antara 3-28 hari pada plastik dan hal ini tentunya berdampak luas pada ekosistem dan organisme (McRobert et al, 2020; hlm. 13).

Michael Northcott (2020) menjabarkan fakta bahwa pengelolaan sampah yang dilakukan pemerintah daerah Bali masih sangat kurang dan bahwa proyek daur ulang dan pemilahan sampah sampai dengan saat ini kebanyakan masih berbasis pada komunitas lokal seperti Rumah Kompos di Ubud, Bali. Meskipun kesadaran masyarakat sudah cukup baik akan lingkungan, utamanya dilakukan sebagai upaya agar bisnis pariwisata tetap berjalan lancar. Namun penelitian ini menyampaikan bahwa kuantitas plastik yang digunakan pada keseharian telah mengalahkan kemampuan praktik pengumpulan sampah secara tradisional dan informal, sehingga tindakan cepat yang kurang baik seperti pembakaran sampah plastik masih kerap dilakukan (Northcott, 2020).

Maslow dalam karyanya yang berjudul $A$ Theory of Human Motivation (1989) merumuskan teorinya yang terkenal yang menunjukkan bahwa tindakan manusia akan selalu diarahkan pada kebutuhan dasar tertentu. Pertanyaan yang perlu kita ajukan pada diri kita adalah apa yang memotivasi tindakan kita secara umum ketika menyangkut lingkungan? (Drackner, 2005; hlm. 177). Fakta bahwa orang memegang nilai-nilai tertentu atau memahami urutan sebuah hal dengan cara tertentu tidak berarti bahwa mereka akan benar-benar berperilaku sesuai dan terlepas dari kenyataan bahwa prioritas ini mungkin atau mungkin tidak valid; tindakan dicampur dengan emosi, politik, dan rasionalitas budaya (Drackner, 2005; hlm. 177). MacRae dan Rodic (2015) dalam artikelnya memaparkan bahwa pada sekitar tahun 2011 silam, seorang pengelola Hutan Monyet di Padangtegal, Ubud-Bali, mengembangkan rencana sistem pengelolaan sampah berdasarkan pengumpulan sampah dari rumah tangga dan bisnis dan pengomposan komponen organik untuk menyediakan pasokan kompos permanen untuk pemeliharaan dan perluasan Hutan Monyet. Mereka kemudian membeli truk, mempekerjakan staf, melengkapinya dengan 
seragam dan peralatan serta menyediakan tempat sampah untuk rumah tangga agar memisahkan sampah organik dan non-organik (MacRae \& Rodic, 2015; hlm. 313). Pengelola Hutan Monyet tersebut kemudian bekerja sama dengan Bali Recycling terkait masalah teknis dan pelatihan. Mereka akan menerima barang daur ulang sementara komponen sampah organik akan dikirim langsung ke Temesi. Sayangnya, hubungan dengan Bali Recycling dirusak oleh pengemudi truk yang menjual bahan sampah untuk daur ulang ke depot pemulung pinggir jalan dengan harga yang lebih tinggi sehingga menyebabkan kemitraan yang menjanjikan itu seketika runtuh. Perbedaan politik dan pribadi antara pendiri proyek dan pemimpin desa tidak dapat diselesaikan dan dia mengundurkan diri (MacRae \& Rodic, 2015). Kisah ini memperlihatkan bahwa tindakan supir truk menggambarkan nilai yang berbeda dari apa yang diwacanakan sebelumnya. Supir truk melakukan hal tersebut dengan berlandaskan pada kepentingan material yaitu uang dan bukan semata pada kepentingan lingkungan.

Kehidupan manusia dan kehidupan benda mati tidak dapat dipisahkan, biasa disebut dengan konsep material culture. Bagaimana sebuah benda mati ini diinvestasikan dengan makna yang tertanam dari pergaulan atau penggunaan yang terjadi. Makna di sekitar mereka berubah seiring waktu. Benda mati tersebut juga berubah melalui penggunaan, kita tidak dapat memisahkan kehidupan manusia dan kehidupan benda. Manusia tidak bisa berinteraksi di dunia tanpa menggunakan benda. Karena itu sampah plastik sebagai benda mati, apalagi dalam keadaan COVID-19 ini, adalah bagian sentral dari penelitian ini. Seperti yang disampaikan oleh Higgin (2016; hlm. 72), sampah itu hidup dengan cerita, jalan setapak yang berantakan menuju kembali ke cara hidup masyarakat.

Dipaparkan oleh MacRae dan Rodic (2015; hlm. 311) sampai tahun 1970an misalnya, sebagian besar hasil dari alat yang digunakan pada kehidupan sehari-hari di Indonesia semuanya dibuat dari bahan organik lokal sehingga ketika tidak lagi digunakan atau dibutuhkan mereka dapat dijatuhkan begitu saja ke tanah dan membiarkannya hingga membusuk dengan sendirinya. Budaya tanpa sampah ini bekerja dengan baik selama beberapa generasi, tetapi tidak beradaptasi dengan baik dengan bahan-bahan baru yang mulai muncul pada tahun 1960-an dan berkembang biak dari tahun 1980-an, terutama kemasan plastik yang hingga saat ini masih kerap diperlakukan dengan cara yang sama, dibuang begitu saja atau dibakar (MacRae \& Rodic, 2015). Sampai saat ini, pemerintah hanya mengambil sedikit tanggung jawab untuk pengelolaan sampah yang pelaksanaan dan penegakannya jauh tertinggal dari peningkatan volume limbah yang dihasilkan. Meski demikian, tidak semua yang dibuang oleh seseorang lantas bermakna sampah pula oleh orang lain, contohnya bagi pemulung. Praktik pengumpulan yang dilakukan pasukan pemulung dengan memungut apa yang mereka anggap sebagai bahan sekunder berharga dari pinggiran jalan maupun sungai dan jurang yang kemudian mereka jual kepada pengumpul bukan hanya memberikan mata pencaharian lebih kepada para pemulung tersebut, namun sekaligus membuat perbedaan yang signifikan terhadap total volume sampah di tempat yang tidak memiliki sistem daur ulang formal (MacRae \& Rodic, 2015). Kementerian Lingkungan Hidup dan Kehutanan juga mengakui bahwa pemulung memiliki peran penting dalam membantu pengelolaan sampah dan pengurangan timbunan sampah di TPA, namun kehadiran pandemi COVID-19 membuat berbagai persoalan dalam kehidupan pemulung seperti terbatasnya ruang gerak dalam memulung akibat dari PSBB dan risiko rentan terinfeksi virus saat blusukan dan bersentuhan dengan sampah, terlebih peningkatan sampah medis yang kerap terjadi, hingga tidak mendapatkan bantuan sosial (Kompas, 2020). Jumlah hasil pulungan yang berkurang drastis, harga sampah pulungan yang menurun hingga 50\%, dan kerepotan untuk menjualnya pun menjadi hal yang paling dirasakan akibat banyak lapak pengepul dan pabrik daur ulang sampah plastik yang tutup sehingga beberapa pemulung dari Depok dan Tangerang menumpuk karungan penuh botol plastik di tempat tinggalnya (Kompas, 2020).

Masalah mendasar sebenarnya terletak pada ketidakmampuan praktik pengelolaan sampah secara tradisional untuk mengatasi dan beradaptasi dengan peningkatan besar dalam volume dan perubahan komposisi aliran sampah dimana kemasan konsumen yang tidak dapat terurai secara hayati seperti plastik memainkan peran yang meningkat (MacRae \& Rodic, 2015). Sampah plastik, bersama dengan asap beracun dari pembakaran sampah yang tidak diatur di rumah dan bisnis, 
merupakan ancaman kesehatan masyarakat yang serius di Indonesia (Northcott, 2020). Menteri Lingkungan Hidup dan Kehutanan Indonesia, Siti Nurbaya Bakar mengatakan, Indonesia telah mengumpulkan lebih dari 1.100 ton limbah medis dari bulan Maret hingga Juni 2020 (Dewi, 2020).

Tidak diragukan lagi, munculnya pandemi COVID-19 telah meningkatkan kompleksitas pengelolaan sampah plastik (Vanapalli et al, 2020). Penelitian di India mengutarakan tanggung jawab individu, aksi korporasi, dan kebijakan pemerintah semuanya diperlukan untuk mencegah kita beralih dari satu bencana ke bencana lainnya di masa depan (Vanapalli et al, 2020). Investasi dan transisi menuju bahan baku daur ulang yang ramah lingkungan seperti bioplastik, peningkatan infrastruktur dan kelayakan lingkungan berkelanjutan dapat menjadi kunci yang penting untuk menangani ledakan limbah plastik selama krisis COVID-19 berlangsung. Meskipun pembatalan dan pelonggaran larangan plastik sekali pakai di India dan beberapa negara lainnya mungkin bersifat sementara, kemungkinan implikasinya pada persepsi konsumen dapat menghambat tujuan jangka panjang untuk bertransisi menuju ekonomi melingkar yang ramah lingkungan (Vanapalli et al, 2020). Dengan demikian, masalah lingkungan telah berubah dari terikat secara lokal dengan efek yang jelas dan segera terlihat menjadi bahaya global yang efeknya baru terlihat setelah rentang waktu yang lama (Wärneryd et al. 1994). 'Krisis lingkungan yang merayap' ini (Wärneryd et al. 1994) adalah ancaman abstrak, yang jauh lebih sulit bagi individu untuk sepenuhnya memahami (Drackner, 2005).

\section{Simpulan dan Saran}

Ketergantungan masyarakat yang meningkat pada plastik selama pandemi COVID-19 mungkin bersifat sementara, namun hal ini dapat mengubah tujuan jangka panjang menuju lingkungan yang lebih sehat, terbebas dari polusi plastik. Secara keseluruhan timbunan sampah di perkotaan menurun sekitar 10\% selama pandemi, namun jika dilihat berdasarkan kategori, sampah plastik sekali pakai mengalami kenaikan (LIPI, 2020; dalam Yuniar, 2020). Jika hal ini dibiarkan berlarut-larut maka segala usaha untuk mengatasi permasalahan global yaitu pengelolaan sampah plastik yang sudah dilakukan di masa lampau akan menjadi sia-sia. Sistem dan infrastruktur yang disediakan pemerintah untuk menangani arus produksi sampah plastik sampai saat ini belum memadai dan membutuhkan inovasi dalam teknologi untuk efisiensi ekonomi dan lingkungan di masa depan. Menata ulang kebijakan yang secara khusus mengatur penggunaan plastik sekali pakai dan kemasan pembungkus yang terbuat dari plastik lainnya dalam pembelanjaan secara daring dapat menjadi langkah awal. Pemulung dan ekosistemnya, termasuk pengepul dan penggiling juga harus dimasukkan dalam neraca pengelolaan sampah sektor informal yang sebaiknya diberikan bantuan sosial khusus. Selain itu, pemberian insentif pada masyarakat yang melakukan pengembalian produk plastik kepada institusi daur ulang juga dapat dilakukan dengan harapan mendorong peningkatan akan pentingnya kesadaran lingkungan dan membantu dalam mencapai pengelolaan sampah plastik yang berkelanjutan di masa depan. Bukanlah hal mudah untuk merubah suatu kebiasaan yang sudah mendarah daging, namun sekiranya masyarakat dan pemerintah, juga badan kesehatan masyarakat, serta institusi-institusi terkait seperti industri produksi plastik bekerja sama dalam mencari solusi untuk mengatasi permasalahan plastik ini segera maka kita bisa mengurangi kemungkinan suatu ledakan masalah lingkungan yang tidak terduga di masa depan akibat pandemi COVID-19.

\section{Daftar Rujukan}

BNPB Indonesia. (2020). Update Infografis Percepatan Penanganan COVID-19 di Indonesia per tanggal 28 November 2020 Pukul 12.00 WIB. Retrieved November 29, 2020, from Twitter website: https://twitter.com/BNPB Indonesia/status/1332612505818959872?s=20

CNBC Indonesia. (2020). Hikmah Corona, Polusi Udara DKI Jakarta Turun Signifikan. Retrieved December 3, 2020, from CNBC Indonesia website: https://www.cnbcindonesia.com/news/20200501190241-4-155748/hikmah-coronapolusi-udara-dki-jakarta-turun-signifikan 
Dewi, R. K. (2020). Mengapa Pandemi Corona Picu Lonjakan Limbah Plastik di Asia Tenggara? KOMPAS. Retrieved November 28, 2020, from KOMPAS.com website: https://www.kompas.com/tren/read/2020/08/10/070000165/mengapa-pandemicorona-picu-lonjakan-limbah-plastik-di-asia-tenggara

Drackner, M. (2005). What is waste? To whom? An anthropological perspective on garbage. Waste management \& research, 23(3), 175-181. DOI: 10.1177/0734242X05054325

Douglas, M. (2001). Purity and danger: An analysis of concepts of pollution and taboo. Taylor \& Francis e-Library.

Eriksen, T. H., \& Schober, E. (2017). Waste and the superfluous: an introduction. Social Anthropology, 25(3), 282-287

Gugus Tugas Percepatan Penanganan COVID-19. (2020). Peta Sebaran. Retrieved November 28, 2020, from https://covid19.go.id/peta-sebaran

Gorrasi, G., Sorrentino, A., \& Lichtfouse, E. (2020). Back to plastic pollution in COVID times. Environmental Chemistry Letters. https://doi.org/10.1007/s10311-020-01129-z

Hamdana R., S. (2020). Fitur Aplikasi Gojek Mudahkan Adaptasi Kebiasaan Baru. Retrieved December 3, 2020, from Bisnis.com website: https://sulawesi.bisnis.com/read/20201009/539/1303007/fitur-aplikasi-gojekmudahkan-adaptasi-kebiasaan-baru

Hidayat, T. (2020). Analisis Persepsi Konsumen Terhadap Pembelian Makanan Secara Online Saat Pandemi Covid-19 (Kasus Fitur Go-Food). Universitas Sumatera Utara. http://repositori.usu.ac.id/handle/123456789/27798

Ikiz, E., Maclaren, V. W., Alfred, E., \& Sivanesan, S. (2020). Impact of COVID-19 on household waste flows, diversion and reuse: The case of multi-residential buildings in Toronto, Canada. Resources, Conservation and Recycling, 164, 105111.

Koentjaraningrat. (2002). Pengantar Ilmu Antropologi (Cetakan Ke-8). Jakarta: PT. RINEKA CIPTA.

MacRae, G., \& Rodic, L. (2015). The weak link in waste management in tropical Asia? Solid waste collection in Bali. Habitat International, 50, 310-316. https://doi.org/10.1016/j.habitatint.2015.09.002

Masrul, M., Tasnim, J. S., Daud Oris Krianto Sulaiman, C. P., Purnomo, A., Febrianty, D. H. S., Purba, D. W., \& Ramadhani, Y. R. (2020). Pandemik COVID-19: Persoalan dan Refleksi di Indonesia. Medan: Yayasan Kita Menulis.

Makki, F., Lamb, A., \& Moukaddem, R. (2020). Plastics and the coronavirus pandemic: a behavioral science perspective. Mind \& Society, 1-5. https://doi.org/10.1007/s11299-020-00258$\underline{\mathrm{w}}$

Maslow, A. H. (1989). A theory of human motivation. Readings in managerial psychology, 20, 20 35.

McRobert, D., Jordan, D., \& Ostrum, M. (2020). How the COVID-19 Pandemic has Reshaped Global Patterns of Plastic Use and the Timing of Regulatory Phase-outs and Possible Progressive Legal, Regulatory and Consumer Responses. Ontario Bar Association. Retrieved November 28, 2020, from Oba.org website: https://www.oba.org/Sections/Environmental-Law/Articles/Articles-2020/October2020/How-the-COVID-19-Pandemic-has-Reshaped-Global-Patt

Menteri Kesehatan Republik Indonesia. (2020). Peraturan Menteri Kesehatan Republik Indonesia Nomor 9 Tahun 2020 Tentang Pedoman Pembatasan Sosial Berskala Besar Dalam Rangka Percepatan Penanganan Coronavirus Disease 2019 (Covid-19). Retrieved July 7, 2020, from http://hukor.kemkes.go.id/uploads/produk hukum/PMK No 9 Th 2020 ttg Pedoma n Pembatasan Sosial Berskala Besar Dalam Penanganan COVID-19.pdf

Neumeyer, X., Ashton, W. S., \& Dentchev, N. (2020). Addressing resource and waste management challenges imposed by COVID-19: An entrepreneurship perspective. Resources, $\begin{array}{llll}\text { Conservation } & \text { and } & 105058 .\end{array}$ https://doi.org/10.1016/j.resconrec.2020.105058 
Northcott, M. S. (2020). Rubbish, Recycling and Religion: Indonesia's Plastic Waste Crisis and the Case of Rumah Kompos in Ubud, Bali. International Journal of Interreligious and Intercultural Studies, 3(1), 1-19. https://doi.org/10.32795/ijiis.vol3.iss1.2020.680

Pathak, G., \& Nichter, M. (2019). The anthropology of plastics: an agenda for local studies of a global matter of concern. Medical anthropology quarterly, 33(3), 307-326.

Rahmawati, D. (2020). Pandemi Corona Virus Gelombang Kedua, Mungkinkah Terjadi? SehatQ. Retrieved July 6, 2020, from https://www.sehatq.com/artikel/covid-19-ditetapkansebagai-pandemi-apa-artinya

Rakhmani, I., Utomo, A., Phillips, C., \& Setyonaluri, D. (2020, August 10). COVID-19, women and digitised food networks in Jakarta: Inequality and Resilience. Melbourne Asia Review. Retrieved December 2, 2020, from Melbourne Asia Review website: https://melbourneasiareview.edu.au/covid-19-women-and-digitised-food-networksin-jakarta-inequality-and-resilience/

Republika. (2020). Pertumbuhan Transaksi Gofood Naik 20 Persen Selama Pandemi. Republika. Retrieved November 30, 2020, from https://republika.co.id/berita/qgswmf370/pertumbuhan-transaksi-gofood-naik-20persen-selama-pandemi

Rupani, P. F., Nilashi, M., Abumalloh, R. A., Asadi, S., Samad, S., \& Wang, S. (2020). Coronavirus pandemic (COVID-19) and its natural environmental impacts. International Journal of Environmental Science and Technology, 1-12. https://doi.org/10.1007/s13762-020$\underline{02910-\mathrm{X}}$

Reno, J. (2015). Waste and waste management. Annual Review of Anthropology, 44, 557-572.

Sarkodie, S. A., \& Owusu, P. A. (2020). Impact of COVID-19 pandemic on waste management. Environment, development and sustainability, 1-10. https://doi.org/10.1007/s10668020-00956-y

Schlehe, J., \& Yulianto, V. I. (2020). An anthropology of waste: Morality and social mobilisation in Java. Indonesia and the Malay World, 48(140), 40-59.

Schlehe, J., \& Yulianto, V. I. (2018). Waste, worldviews, and morality at the South Coast of Java: an anthropological approach. Occasional Paper, 41.

Shammi, M., \& Tareq, S. M. (2020). Environmental Catastrophe of COVID-19: Disposal and Management of PPE in Bangladesh. Global Social Welfare, 1-4. https://doi.org/10.1007/s40609-020-00195-z

Singer, M. (2020). COVID-19 and The Lessons Anthropology Learned from HIV/AIDS. Retrieved December 2, 2020, from Somatosphere Web site: http://somatosphere.net/2020/covidlessons-anthropology.html/

Kompas. (2020). Pemulung Hadapi Berlipat Masalah Saat Pandemi Covid-19 - Kompas.id. Retrieved December 8, 2020, from Kompas.id website: https://kompas.id/baca/humaniora/kesehatan/2020/05/11/pemulung-hadapiberlipat-masalah-saat-pandemi-covid19/? t=aQPw59D719ZGYGMiAU7NqZ9Cd7q0vkiKSjgNAPKD4kU1eUjfa65hcB4ZdQsE63 L7\#

Urban, R. C., \& Nakada, L. Y. K. (2020). COVID-19 pandemic: Solid waste and environmental impacts in Brazil. Science of the Total Environment, 755, 142471.

Vanapalli, K. R., Sharma, H. B., Ranjan, V. P., Samal, B., Bhattacharya, J., Dubey, B. K., \& Goel, S. (2020). Challenges and strategies for effective plastic waste management during and post COVID-19 pandemic. Science of The Total Environment, 750, 141514.

Wirakusuma, K. Y. (2020, April 11). Langit Biru Jakarta. MEDCOM ID. Retrieved December 3, 2020, from medcom.id website: https://www.medcom.id/rona/kesehatan/GNG4jPdb-langitbiru-jakarta

World Health Organization. (2020). WHO Coronavirus Disease (COVID-19) Dashboard. Retrieved November 28, 2020, from https://covid19.who.int/ 
Yuniar, R. W. (2020). Larangan plastik di tengah PSBB Jakarta: 'butuh terobosan baru' atur penggunaan plastik di belanja online. BBC News Indonesia. Retrieved December 2, 2020 , from https://www.bbc.com/indonesia/majalah-53275980 